口絵 2 : 積雪期の青森市におけるバス交通と居住者の様相

\title{
Pictorial 2 : Scene Showing Bus Transportation and Residents in Aomori City during the Snow Season
}

青森市（本特集号，秋元（2016）の分析対象地域）は全域が特別豪雪地帯に指定されており，都心部においても積雪がみら れる（図 1).ノンステップ仕様でないバスでは，高齢者などが荷物を下げての乗降車に手間取る場面もみられた。また，停 留所は吹きさらしの構造であるため, 悪天候の日にバスを待つことは大変である

郊外住宅地の 1 つである戸山団地における中心的なバス停には簡易な覆いが設置されているが, 風雨を完全に防ぐための扉 はなく，暴風の場合には雨雪と厳しい寒さのなかでバスを待たなくてはならない（図 2). バスが到着する直前になると乗客 が集まり，住民は時刻表にあわせて公共交通サービスを効率的に利用している様子がうかがえる.

戸山団地は傾斜のある地形上に建設されており，急な坂道が多い. 団地の中心部に商業施設などの生活関連施設が立地して おり，それら施設を利用するためには坂道を上り下りしなくてはならない。除雪された雪が自動車の高さを超えて路肩に積み 上げられ，厚い雪で覆われている歩道を，買い物を済ませた住民が上っていく様子がみられる（図 3 )。 とくに高齢者が荷物 を抱えて移動することは困難であり，危険でもある．

All of Aomori city is blanketed in snow (analyzed in Akimoto (2016) of this special issue), including the central area (Fig. 1). It can be seen that elderly people with bags have difficulty getting on or off a bus that has steps. It is also tough to wait for a bus at an unfenced bus stop when the weather is foul.

Although the central bus stop located in Toyama Danchi, a suburban housing district, is covered with simple boards, there is no door to shut out the wind and heavy rain (Fig. 2). People have to wait for a bus in a rain-swept, snowy, and cold space during a storm. Passengers come to the bus stop just before a bus is due to arrive, which means residents can use public transportation services efficiently with the help of a bus timetable.

The Toyama housing district is constructed on a slope and there are many hilly roads. Facilities for daily use such as shops are located in the central zone, and it is necessary to walk up and down steep roads to access those facilities. The walkways are covered with thick snow in spite of being cleared with a snowplow. Then, it is difficult and dangerous for residents, especially elderly people, to walk on such roads with carrying shopping bags (Fig. 3 ).
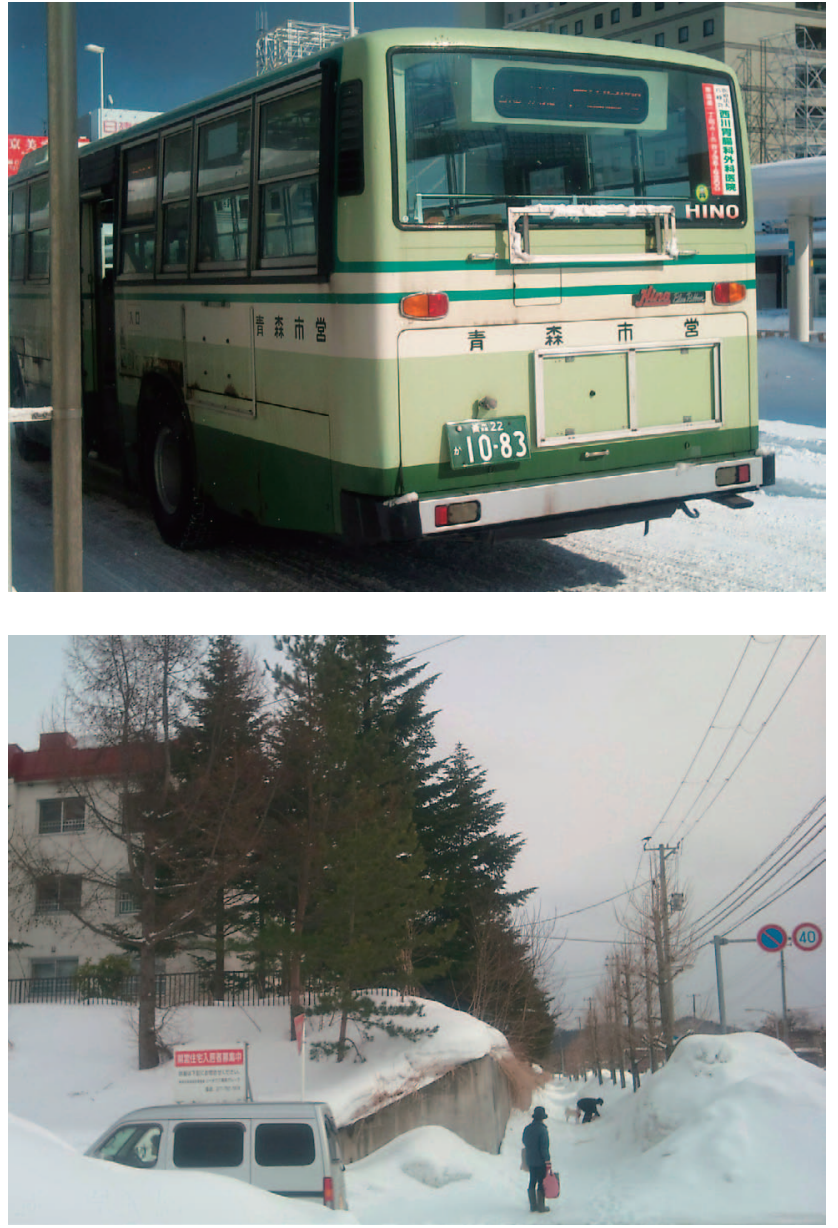

図 3 戸山団地で雪の坂道を上る居住者 (2013 年 2 月撮影).

Fig. 3 Residents walking up a hill covered with snow in Toyama housing district (taken in February, 2013).
図 1 青森駅前に停車中の「戸山団地」行き市営バス（2013 年 2 月撮影)

Fig. 1 City bus bound for Toyama housing district stopping at Aomori station (taken in February, 2013).

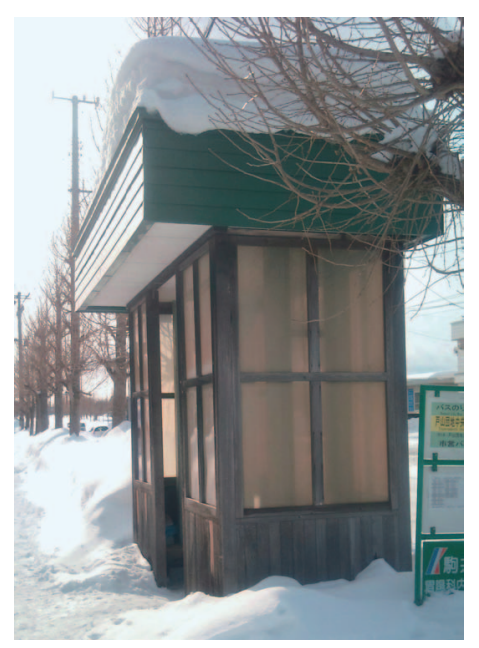

図 2 戸山団地における中心的なバス停「戸山団 地中央通り」(2013 年 2 月撮影).

Fig. 2 Toyama-danchi-chuo-dori, the central bus stop of the housing district (taken in February, 2013).

文献

秋元菜摘 $(2016)$ : 一極集中型コンパクトシティ政策の有効性に 関するアクセシビリティのシミュレーション分析一青森市に おける人口の集約化と公共交通の多頻度化一. 地学雑誌, 125, 523-544. [Akimoto, N. (2016): Implications of centralized compact city designs for accessibility from simulation analyses: Improving population distribution and public transportation in Aomori city. Journal of Geography (Chigaku Zasshi), 125, 523-544. (in Japanese with English abstract) ] 